\title{
The Efficiency of PAH Metabolites Fluorescence Intensity Measurement to Study Pahs Contamination
}

\author{
Khobkul Nongnutch $^{1}$, Jakkaphun Nanuam ${ }^{2} \&$ Chawanrat Somnuek ${ }^{3}$ \\ ${ }^{1}$ Faculty of Industrial and Technology, Rajamangala University of Technology Isan Sakon Nakhon Campus, \\ Sakon Nakhon, Thailand \\ ${ }^{2}$ Faculty of Science and Social Sciences, Burapha University, Sakaeo, Thailand \\ ${ }^{3}$ Faculty of Science, Rambhai Barni Rajabhat University, Chantaburi, Thailand \\ Correspondence: Khobkul Nongnutch, Faculty of Industrial and Technology, Rajamangala University of \\ Technology Isan Sakon Nakhon Campus, Sakon Nakhon, Thailand. Tel: 66-818-196-766. E-mail: \\ khopkul25@gmail.com
}

Received: October 8, 2011 Accepted: March 8, 2012 Online Published: June 1, 2012

doi:10.5539/enrr.v2n2p32 URL: http://dx.doi.org/10.5539/enrr.v2n2p32

\begin{abstract}
The aim of this study was to evaluate the efficiency of fluorescence intensity measurement of PAH metabolites in fish bile (by Fixed Wavelength Fluorescence, FF) to study and assess PAHs contamination in aquatic organism. Nile tilapia (Oreochromis niloticus) was exposed to benzene, fluorene, anthracene, chrysene, and benzo[a]pyrene at non-lethal concentrations. The results showed that the fluorescence intensity and EROD activity were significantly increased with increase in exposure times and PAH concentrations. Moreover, the results of both methods had significantly positive relation. The maximum values were reached in 16 day after exposure. Thus, fluorescence intensity measurement by FF technique could be used as a potential tool for environmental study in the case of PAHs contamination in aquatic environment.
\end{abstract}

Keywords: PAHs, EROD activity, fixed wavelength fluorescence, Nile tilapia

\section{Introduction}

PAHs, a group of carcinogenic substance, are widely found in the environment especially in the aquatic environment created and released during the incomplete combustion of organic materials, especially fossil fuel such as oil and coal (Brion \& Pelletier, 2005).

In the aquatic environment, they are found accumulate in both organisms and sediments because of their very low water solubility (Björk, 1995; Baumard et al., 1998; Ching et al., 2000). In the organism body, they are transformed to the metabolite with higher water solubility by enzymes in detoxification process (Machella et al., 2005). However, these processes can also stimulate their carcinogenic property making them attach on DNA chain and then disturb DNA translation and transcription (Machella et al., 2005; Yang \& Baumann, 2006).

Due to the effect of PAHs on the organisms mentioned above, the environmental scientist have looked for the best practices or techniques with fast, easy, reliable, and non expensive to study and monitor their fate, transformation processes, accumulation and effecting mechanisms in the organism body. A method wildly used is Ethoxyresourfin-O-Deethylase (EROD) activity measurement (Blanc et al., 2010; Bosveld et al., 2002; Fouchécaurt et al., 1999; Shaw et al., 2004; Yang \& Baumann, 2006). This method have the advantage of antigen-antibody specific making it very reliable, however, it requires more experimental skill of worker and quite expensive. Thus, we want to look for the potential alternative method; PAHs metabolite fluorescence intensity measurement by Fixed wavelength fluorescence (FF). This method have been used in some studied (Beyer et al., 2010; Neves et al., 2007) because of its quite simple, fast, reliable, and non expensive.

The aim of this study was to evaluate the efficiency of PAHs metabolite fluorescence intensity measurement by comparing with EROD activity measurement to study PAHs contamination in the aquatic environment.

\section{Materials and Methods}

The representative organisms used in this study was male Nile tilapia (Oreochromis niloticus) measuring 3-4 inches. They were obtained from the Chonburi Inland Fisheries Research and Development Center, Chonburi provence, Thailand. Before the experiment, they were allowed to acclimatize the new environment for about 1-2 
weeks in $1 \mathrm{~m}^{3}$ tank with aerated tap water and constant temperature of $23.0-25.5^{\circ} \mathrm{C}$. Approximately, $5 \%$ of the water in this tank was replaced every day. After that, the fish was transferred to the experimental tank and divided into 7 groups; 6 experimental groups and a control group. The experimental groups exposed to benzene, fluorene, anthracene, chrysene and benzo[a]pyrene in concentration of $0.05,0.1,0.5$, and $1.0 \mathrm{ppm}$ (selecting based on $\mathrm{LC}_{50}$ and NOEL at $96 \mathrm{~h}$ ) while the control group exposed to $0.2 \mathrm{ml} / 1$ acetonitrile. All treatment was tested in continuous flow condition and $4 \%$ of treated water with same PAHs concentration was replaced every day. Daily values of $\mathrm{pH}, \mathrm{DO}$, and temperature were recorded. Next, the fish samples were taken at $0,2,4,8$, and 16 day. Fish bile metabolites was extracted by using the method modified from Aas et al. (1998) and Britvic, Lucie, \& Kurelec (1993), then the metabolites was measured the fluorescence intensity. Fish liver was extracted to measure EROD activity following the method of ICES (1998) and Burke \& Mayer (1974). For statistical analysis, the variance was analyzed by ANOVA and the normal of data testing was analyzed by Shapiro-Wilk test and log-transformed. SPSS analysis was done for evaluate the relation between the fluorescence intensity of PAHs metabolites in bile and EROD activity level in liver at confidential level of $95 \%$.

\section{Results and Discussion}

\subsection{Pahs Metabolites Fluorescence Intensity}

Figure 1 shows the fluorescence intensity of benzene metabolite, fluorene metabolite, anthracene metabolite, chrysene metabolite, and benzo[a]pyrene metabolite in fish bile which was significantly increased with an increasing in exposure time and the highest intensity was reached at 16 day after exposure.

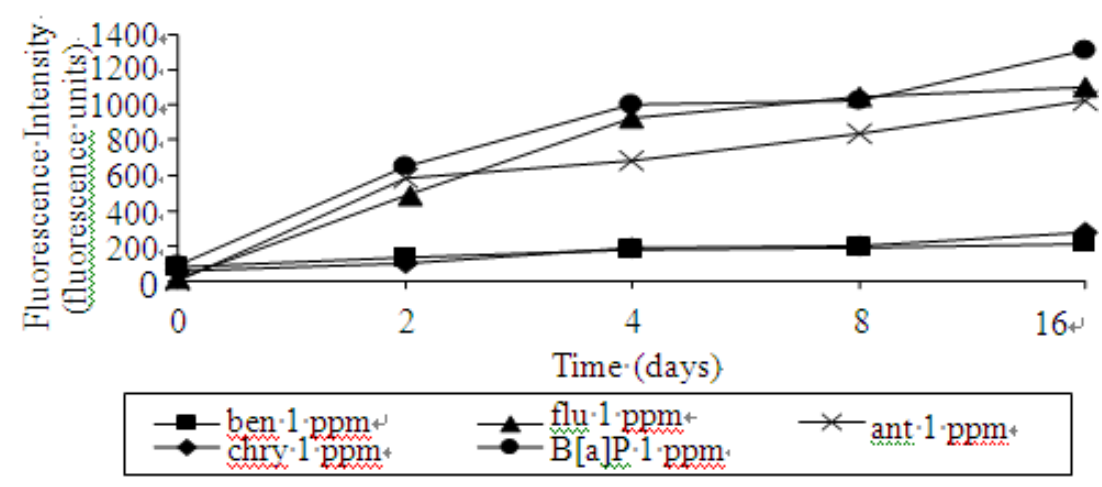

Figure 1. Fluorescence intensity of benzene metabolite, fluorene metabolite, anthracene metabolite, chrysene metabolite, and benzo[a]pyrene metabolite in fish bile

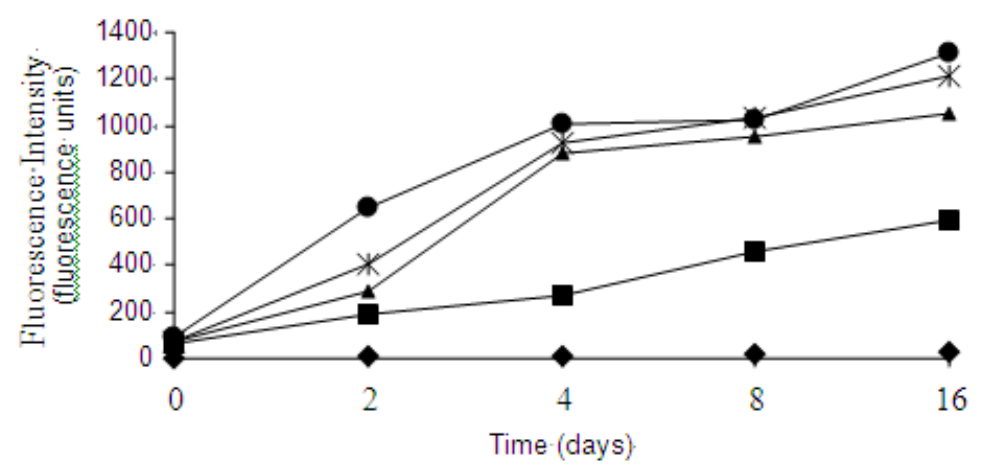

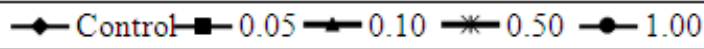

Figure 2. Fluorescence intensity of benzo[a]pyrene metabolite

From figure 2, the result shows that the fluorescence intensity of benzo[a]pyrene metabolite was significantly 
increased with an increasing in benzo[a]pyrene concentration. The highest fluorescence intensity was reached in the concentration of $1.0 \mathrm{mg} / \mathrm{l}$.

An increasing in fluorescence intensity of PAHs metabolites with exposure time and PAHs concentration may be the response of fish immunological system to toxicant exposure (Machella et al., 2005). When the fish exposed to PAHs, PAHs were transformed to metabolites by CYP1A enzyme in detoxification process (Skarphéðinsdóttir et al., 2003). Thus, the amount PAHs metabolite (shown in fluorescence intensity) was increased with exposure time and PAHs concentration. The results found in this study is in agreement with the studies of Yang \& Baumann (2005), Aas \& Goksoyr (1998), and Aas et al. (2000), they found that the fluorescence intensity in exposed fish was increased with exposure time and PAHs concentration compared to those in the control.

\subsection{EROD Activity}

Figure 3 and 4 show that EROD activity in exposed fish was increased with exposure time and PAHs concentration. Due to EROD activity is measuring the amount of CYP1A enzyme, which induced by PAHs exposure, thus it was increased when fished expose to the inducer (Blanc et al., 2010; Shaw et al., 2004; Yang \& Baumann, 2006).This result is in agreement with the study of Shaw et al. (2004) which found that EROD activity in yellowfin bream (Acanthopagrus australis) was clearly increased in the sample collected from PAHs contaminated area.

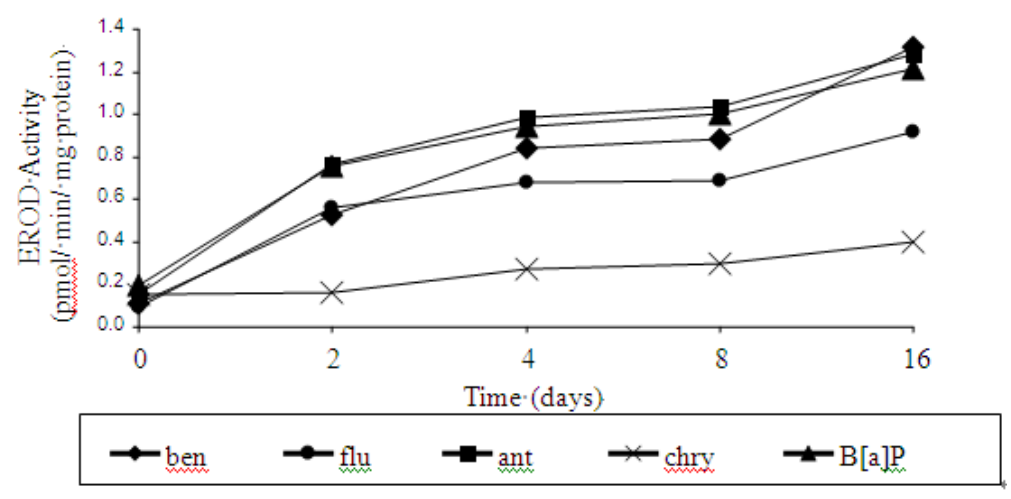

Figure 3. EROD activity in fish exposed to PAHs

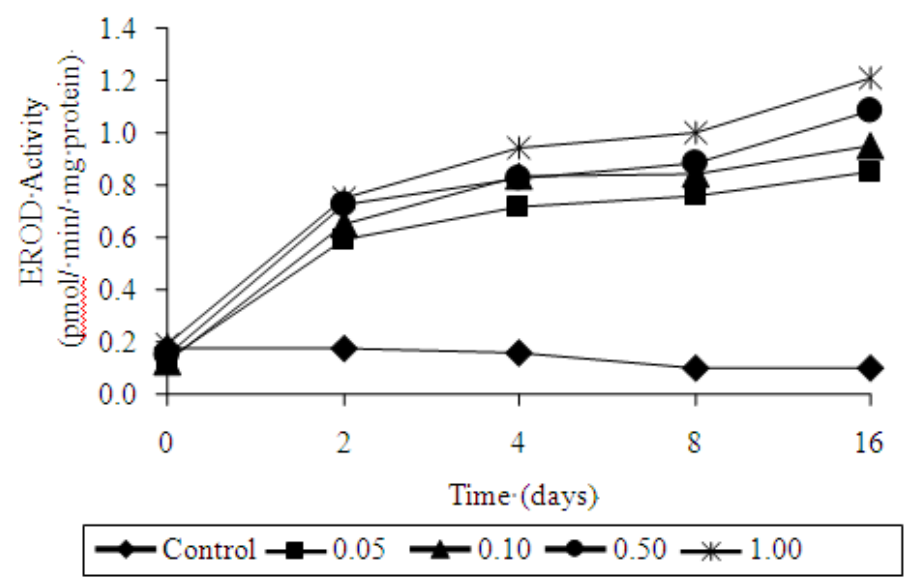

Figure 4. Increasing in EROD activity with benzo[a]pyrene concentration

\subsection{The Relationship Between Pahs Metabolites Fluorescence Intensity and EROD Activity}

All the results shown above indicate that the fluorescence intensity of PAHs metabolites in fish bile and EROD activity in the liver has significantly positive relation which is increased with exposure time and PAHs concentration (shown in Figure 5 and 6). 


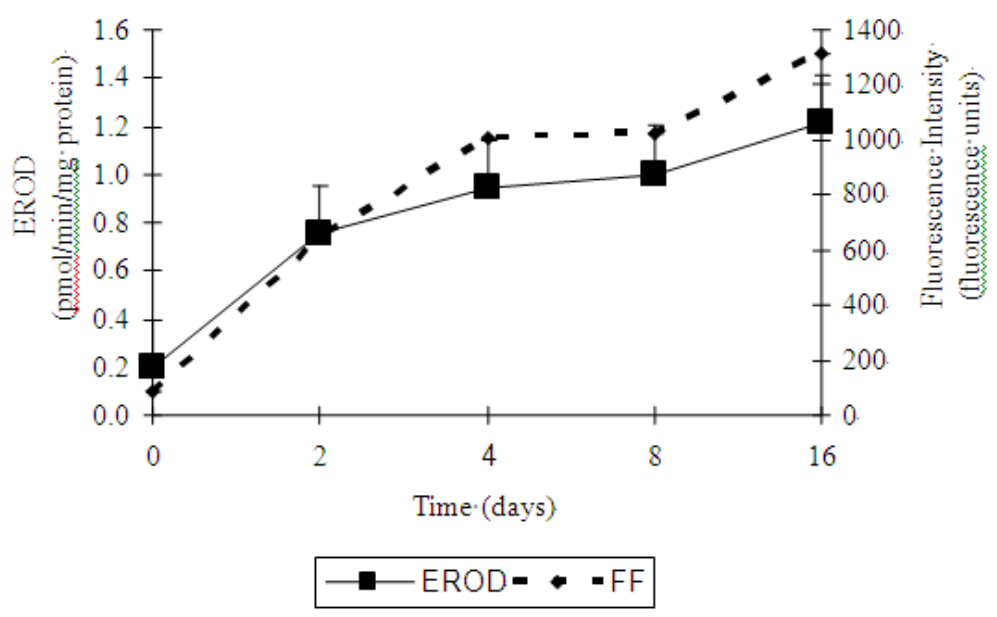

Figure 5. Fluorescence intensity and EROD activity relationship against time exposure
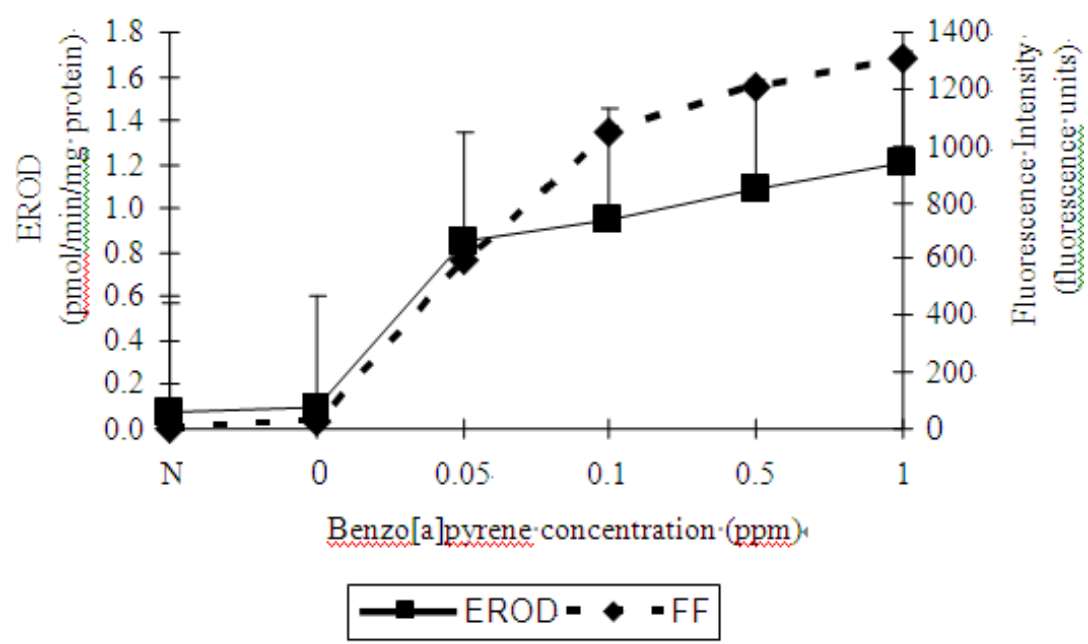

Figure 6. Fluorescence intensity and EROD activity relationship against benzo[a]pyreneconcentration

Due to the EROD activity measurement represents the amount of CYP1A enzyme (involves in phase I of detoxification) which is induced by PAHs exposure and the PAHs metabolite fluorescence intensity measurement represents the amount of PAHs metabolites which is the product of PAHs transformation process, thus the results of both measurements are significantly positive relations and increase with exposure time and PAHs concentration.

\section{Conclusion}

In general, the environmental scientist wants to use the reliable tool to study and monitor PAHs contamination in the environment especially in aquatic environment. However, the method which is appropriate to use should be fast, non expensive and especially reliable. The result of this study confirms that fluorescence intensity measurement of PAH metabolites in fish bile by FF technique can fulfill that requirement of environmental study.

\section{Acknowledgements}

This research was supported by Rajamangala University of Technology Isan, and Chonburi Inland Fisheries Research and Development Center, Thailand. 


\section{References}

Aas, E., Beyer, J., \& Goksøyr, A. (1998). PAH in fish bile detected by fixed wavelength fluorescence. Marine Environmental Research, 46, 225-228. http://dx.doi.org/10.1016/S0141-1136(97)00034-2

Aas, E., \& Goksøyr, A. (1998). PAH Metabolite in bile and EROD activity in North Sea fish. Marine Environmental Research, 46, 229-232. http://dx.doi.org/10.1016/S0141-1136(97)00035-4

Aas, E., Baussant, T., Balk, L., \& Liewenborg, B. (2000). PAH metabolites in bile cytochrome P4501A and DNA adducts as environmental risk parameters for chronic oil exposure: a laboratory experiment with Atlantic cod. Aquatic Toxicology. 51, 241-258. http://dx.doi.org/10.1016/S0166-445X(00)00108-9

Barra, R., Sanchez-Hernandez, J. C., Orrego, R., Parra, O., \& Gavilan, J. F. (2001). Bioavailability of PAHs in the Biobio river (Chile): MFO activity and biliary fluorescence in juvenile. Oncorhynchus mykiss Chemosphere. 45, 439-444. http://dx.doi.org/10.1016/S0045-6535(01)00041-8

Baumard, P., Budzinski, H., Michon, Q., Garrigues, P., Burgeot, T., \& Bellocq, J. (1998). Origin and bioavailability of PAHs in the Mediterranean Sea from mussel and sediment records. Estuarine, Coastal and Shelf Science. 47, 77-90. http://dx.doi.org/10.1006/ecss.1998.0337

Britvic, S., Lucic, D., Kurelec, B. (1993). Bile fluorescence and some early biological effect in fish as indicators of pollution by xenobiotics. Environmental Toxicology and Chemistry, 12, 765-773. http://dx.doi.org/10.1002/etc.5620120418

Beyer, J., Jonsson, G, Ported, C., Krahn, M. M., \& Ariese, F. (2010). Analytical methods for determining metabolites of polycyclic aromatic hydrocarbon (PAH) pollutants in fish bile: A review. Environmental Toxicology and Pharmacology, 30, 224-244. http://dx.doi.org/10.1016/j.etap.2010.08.004

Björk, M. (1995). Bioavailability and uptake of hydrophobic organic contaminants in bivalve filter-feeders. Annales Zoologici Fennici, 32, 237-245.

Blanc, A. M., Holland, L. G., Rice, S. D., \& Kennedy, C. J. (2010). Anthropogenically sourced low concentration PAHS: In situ bioavailability to juvenile Pacificsalmon. Ecotoxicology and Environmental Safety. 73, 849-857. http://dx.doi.org/10.1016/j.ecoenv.2010.03.003

Boonyatumanond, R., Wattayakorn, G., Togo, A., \& Takada, H. (2006). Distribution and origins of polycyclic aromatic hydrocarbons (PAHs) in riverine, estuarine, and marine sediments in Thailand. Marine Pollution Bulletin. 52, 924-956. http://dx.doi.org/10.1016/j.marpolbul.2005.12.015

Bosveld, A. T. C., Paul A. F. de Bie, Nico W. van den Brink, Hester Jongepier, H., \& Klomp, A. V. (2002). In vitro EROD induction equivalency factors for the 10 PAHs generally monitored in risk assessment studies in The Netherlands. Chemosphere, 49, 75-83. http://dx.doi.org/10.1016/S0045-6535(02)00161-3

Brion, D. \& Pelletier, É. (2005). Modeling PAHs adsorption and sequestration in freshwater and marine sediments. Chemosphere. 61, 867-876. http://dx.doi.org/10.1016/j.chemosphere.2005.04.097

Burke, M. D., \& Mayer, R. T. (1974). Ethoxyresorufin: Direct fluorimetric assay of a microsomal- O-dealkilation which is preferentially inducible by 3-methylcholanthrene. Drug Metabolism and Disposition, 2, 583-588.

Chen, Y., Zhu, L., \& Zhou, R. (2007). Characterization and distribution of polycyclic aromatic hydrocarbons in surface waters and sediments from Qiantang River, China. Journal of Harzardous Materials,141, 148-155. http://dx.doi.org/10.1016/j.jhazmat.2006.06.106

Chen, B., Xuan, X., Zhu, L., Wang, J., Gao, Y., Yang, K., Shen, X., \& Lou, B. (2004). Distributions of polycyclic aromatic hydrocarbons in surface waters, sediments and soils of Hangzhou City, China. Water Research. 38, 3558-3568. http://dx.doi.org/10.1016/j.watres.2004.05.013

Ching, E. W. K., Siu, W. H. L., Lam, P. K. S., Xu, L., Zhang, Y., Richardson, B. J., \& Wu, R. S. S. (2000). DNA adduct formation and DNA strand breaks in Green-lipped mussels (Perna viridis) exposed to benzo[a]pyrene: dose- and time- dependent relationships. Marine pollution bulletin. 42, 603-610. http://dx.doi.org/10.1016/S0025-326X(00)00209-5

Coamus, L., Aas, Endre., \& Borseth, J. F. (1998). Ethoxyresorufin-O-deethylase activity and fixed wavelength fluorescence detection of PAHs metabolites in bile in turbot (Scophthalmus maximus L.) exposed to a dispersed topped crude oil in a continuous flow system. Marine Environmental Research. 46, 29-32. http://dx.doi.org/10.1016/S0141-1136(97)00045-7

Dissanayake, A., \& Galloway, T. S. (2004). Evaluation of fixed wavelength Fluorescence and synchronous 
fluorescence spectrophotometry as a biomonitoring tool of environmental contamination. Marine Environmental Research, 58, 281-285. http://dx.doi.org/10.1016/j.marenvres.2004.03.072

Ferreira, M., Moradas-Ferreira, P., \& Ries-Henriques, M. A. (2006). The effect of long-term depuration on phase I and phase II biotransformation in mullets (Mugil cephalus) chronically exposed to pollutants in River Douro Estuary, Portugal. Marine Environmental Research. 61, 326-338. http://dx.doi.org/10.1016/j.marenvres.2005.11.001

Fouchécourt, M. O., Arnold, M., Berny, P., Videmann, B., Rether, B., \& Riviére, J. L. (1999). Assessment of the Bioavailability of PAHs in Rats Exposed to a Polluted Soil by Natural Routes: Induction of EROD Activity and DNA Adducts and PAH Burden in Both Liver and Lung. Environmental research section A., 80, 330-339.

Fuentes-Rios, D., Orrego, R., Rudolph, A., Mendoza, G., Gavilan, J. F., \& Barra, R. (2005). EROD activity and biliary fluorescence in Schroederichthys chilensis (Guichenot 1848): Biomarkers of PAH exposure in coastal environments of the South Pacific Ocean. Chemosphere. 61, 192-199. http://dx.doi.org/10.1016/j.chemosphere.2005.02.062

GoksØyr, A., \& Forlin, L. (1992). The cytochrome P450 system in fish, aquatic toxicology and environmental monitoring. Aquatic Toxicology. 22, 287-312. http://dx.doi.org/10.1016/0166-445X(92)90046-P

Gorbi, S., \& Regoli, F. (2004). Induction of cytochrome P4501A and biliary PAH metabolites in European eel Anguilla anguilla: Seasonal, dose- and time-response variability in field and laboratory conditions. Marine Environmental Research, 58, 511-515. http://dx.doi.org/10.1016/j.marenvres.2004.03.038

Harayama, S. (1997). Polycyclic aromatic hydrocarbon bioremediation design. Curr OpinBiotechnol, 8, 268-273. http://dx.doi.org/10.1016/S0958-1669(97)80002-X

Inzunza, B., Orrego, R., Penalosa, M., Gavilan, F. J., \& Barra, R. (2006). Analysis of CYP4501A1, PAHs metabolites in bile, and genotoxic damage in Oncorhynchus mykiss exposed to Biobio River sediments, Central Chile. Ecotoxicology and Environmental Safety. 65, 242-251. http://dx.doi.org/10.1016/j.ecoenv.2005.07.019

Machella, M., Regoli, F., \& Santella, R. M. (2005). Immunofluorescent detection of 8-oxo-dG and PAH bulky adducts in fish liver and mussel digestive gland. Aquatic Toxicology. 71, 335-343. http://dx.doi.org/10.1016/j.aquatox.2004.12.002

Neves, R. L. S., Oliveira, T. F., \& Ziolli, R. L. (2007). Polycyclic aromatic hydrocarbons (PAHs) in fish bile (Mugil liza) as biomarkers for environmental monitoring in oil contaminated areas. Baseline Marine Pollution Bulletin, 54, 1813-1838.

Shaw, J. P., Peters, L. D., \& Chipman, J. K. (2004). CYP1A- and CYP3A- immunopositive protein levels in digestive gland of the mussel Mytilus galloprovincialis from the Mediterranean Sea. Marine Environmental. 58, 649-653. http://dx.doi.org/10.1016/j.marenvres.2004.03.056

Skarphéóinsdóttir, K., Ericson, G., Zuanna, L. D., \& Gilek, M. (2003). Tissue differences, dose-response relationship and persistence of DNA adducts in blue mussels (Mytilus edulis L.) exposed to benzo[a]pyrene. Aquatic Toxicology. 62, 165-177. http://dx.doi.org/10.1016/S0166-445X(02)00102-9

Vuorinen, P. J., Keinanen, M., Vountisjarvi, H., Barsiene, J., Broeg, K., Forlin, L., Gercken, J., Kopecka, J., Kohler, A., Parkkonen, J., Pempkowiak, J., \& Schiedek, D. (2006). Use of biliary PAH metabolites as a biomarker of pollution in fish from the Baltic Sea. Marine Pollution Bulletin. 53, 479-487. http://dx.doi.org/10.1016/j.marpolbul.2005.11.020

Yang, X., \& Baumann, P. C. (2005). Biliary PAH metabolites and the hepatosomatic index of brown bullheads $\begin{array}{llllll}\text { from Lake Erie tributaries. Ecological Indicators. } & \text { 6, }\end{array}$ http://dx.doi.org/10.1016/j.ecolind.2005.08.025 